\title{
Sheikh Muhammad Walī Al-Khalidī’s Idea about the Education Concept of Tazkiyatun Nafsi
}

\author{
Rusdi Kurnia \\ Tapaktuan State Islamic College \\ rusdikurnial8@yahoo.com
}

\begin{abstract}
This study aims to discuss about idea of Sheikh Muhammad Walī Al-Khalidī about the education concept of Tazkiyatun Nafsi. He was born in Blang Poroh Village, Labuhan Haji Subdistrict, South Aceh Regency, in 1338 H. Suluk is to train the teachings of tariqat to come true. This training is the beginning to be able to follow the Sunnah of the Messenger and hold the syariah'atnya and behave with his morals. When walking the path of suluk, a salik is given psycho-spiritual education from the mursyid. Every time, the mursyid always pays attention to the physical and non-physical situations and conditions found in the salik. This condition is a guide for the mursyid in guiding salik. This pattern of education will influence the mindset and remembrance pattern of a salik. Unnoticed by a salik that a murshid has formed a new psychology for salik to always get closer to Allah.
\end{abstract}

Keywords : Sheikh Muhammad Walì Al-Khalidī; concept of education; Tazkiyatun Nafsi

\section{Introduction}

Ulama as heirs of the prophet, have a position and function and charisma in the midst of society, because they have extensive knowledge to educate and lead society so that people can distinguish between right and wrong, halal and haram, which are appropriate and which are not feasible. ${ }^{1}$ Abuya Sheikh Muhammad Walīal-Khalidī (hereinafter known as the popular name among the people of Sheikh Muhammad Walī), who was a young ulama who had contributed much to the nation and religion.

Sheikh Muhammad Wali was known as a theologian and Sufi from the Sunni school, especially in matters of education, both in relation to Islamic education and mu'amalah in society philosophically, theoretically and applied. Since childhood, he has been known as a child who likes science and seeks essential truth, even though he is confronted with such a tough challenge.

Sheikh Muhammad Walī had a very important role in developing Islamic education in Aceh, one of which was by printing ulama cadres through his dayah educational institutions, both the dayah in Padang-West Sumatra and the dayah who were pioneered after returning to Aceh. Students from their education are scattered everywhere both in Aceh and throughout the archipelago. ${ }^{2}$

Sheikh Muhammad Walī's struggle in developing religion and printing great scholars was highly valued and emulated. Because on May 7, 2007, the scholars who participated in the high forum of Acehnese clerics at the Baiturrahman Grand Mosque, which is a mosque of pride of the Acehnese people, gave the title of Sheikh Mudawaly as "Ulama 'Arif Billah." has also been appreciated by central and regional governments. During a meeting at the Dayan Daod Building, Syiah Kuala Banda Aceh University on September 2, 2008, attended by various elements, Sheikh Muhammad Walī was appointed as a figure in Aceh education.

\footnotetext{
${ }^{1}$ Sabri A, et, all Biografi Ulama-Ulama Aceh Abad XX Jilid I, $1^{\text {st }}$ Edition, (Dinas Pendidikan Provinsi NAD, 2003), Page. 2.

${ }^{2}$ Musliadi. Abuya Syeikh Muda Waly al-Khalidi (1917-1961 M), (Darussalam, 2013), Page.3.

DOI : https://doi.org/10.33258/birci.v2i1.196 
Sheikh Muhammad Walī is a scientist with broad insight. Some of his essays show his scholarship, including: Tanwīrul Anwar, al-Fatawā, Zikir Ismu Zat,Obat Hati, Permata Intan and other works, compiled in Indonesian written in Jawi Arabic.

Although he was a scientist, finally he chose Sufi as a way of purifying the soul (tazkiyatun nafsi) through thariqatnagsyabandiyah to attain ultimate truth. Sheikh Mu'ammad Wali was seen as a unifying figure of Sufis and jurists, especially in the Province of Aceh and the archipelago in general.

The author chose research on the concept of tazkitatun nafsi nterpretation in this paper, because of some of the features possessed, as described above. And the contribution of his ideas in the field of education, especially the problem of Islamic education, namely tazkitatun nafsi education, so it is interesting for the author to examine it. Besides that, it is a matter of pride for the author because he has appointed a great figure of Islam from South Aceh and Aceh in general and a motivation for personal writers because the spirit of Sheikh Mudawaly is so great in demanding knowledge and reviving religion. This inspires the writer to examine: "Tazkiyatun Nafsi Educational Concept in Perspective of Thought Muhammad Wali al-Khalidī."

\section{Biography of Sheikh Muhammad Walīal-Khalidī}

Abuya Sheikh H. Mu'ammad Walī al-Khalidī was born in Blang Poroh Village, Labuhan Haji Subdistrict, South Aceh Regency, in 1338 H / 1917 M. He died at the age of 43 years, Tuesday March 20, 1961 AD, with 11 Shawwal 1381 H, at 3:30 p.m. ${ }^{3}$

He was the youngest of five children sons and daughters of Sheikh H. Mu'ammad Salim bin Malin Palito. His father came from Batu Sangkar, West Sumatra. He came to South Aceh as the Da i. Previously, his famous uncle was called the Labuhan Haji community with Tuanku Pelumat whose real name was Sheikh Abdul Karīm who had previously settled in Labuhan Haji. His uncle was also a da'i and an Islamic teacher there.

Not long after Sheikh Muhammad Salim settled in Labuhan Haji, he was betrothed to a woman named Siti Janadat, the daughter of a village head named Keuchik Nya 'Exam from the Village of Palak City, Labuhan Haji District, South Aceh. Siti Janadat died while giving birth to the sister of Sheikh Muhammad Walī. He died with his baby. At that time, Abuya was six years old and he was cared for by his stepmother who was known to the public by calling Mak Induak. However, the marriage of his parents to Umi did not last long.

Sheikh Mu'ammad Salīm loved Sheikh Muhammad Walī more than his other brothers. Wherever he went to teach and proclaimed Shaykh Muhammad Wali was always carried by his father. Maybe Sheikh Muhammad Salīm had a premonition that one day his son would become a great ulama, especially when Sheikh Muhammad Walīmasih was in the womb, he dreamed of a full moon descending into his lap.

Name of Abuya Sheikh H. Muḥammad Walī al-Khalidī at small time was Muhammad Walī. When he was in West Sumatra, he was called with the title Angku Mudo or Angku Mudo Walī or Angku Aceh. After he returned to Aceh, the community called him with

${ }^{3}$ Musliadi. Abuya Syeikh Muda Walī al-Khalid̄̄ (1917-1961 M), (Darussalam, 2013), page 4.

DOI : https://doi.org/10.33258/birci.v2i1.196 
Teungku Young Walī or now known as Abuya Sheikh Muda Walī. ${ }^{4}$ While he often wrote his own name with Muhammad Walī or the complete Shi'ite Hajj Muḥammad Walī al-Khalidī.

Abuya Muhammad Walī has four wives, namely $\mathrm{Hj}$. Rasimah (Umi Padang), $\mathrm{Hj}$. Raudhati Nur (Umi Paoh), Hj. Rasimah (Umi Manggeng), Hj. Siti Aisyah (Umi Teunom). Abuya married such a woman was not because she was a crazy woman, or her lust. But his marriage was mostly the demand from the local community for the sake of da'wah and religious development. ${ }^{5}$

\section{Discussion}

To study the thought of Sheikh Muhammad Walī al-Khalidī, on the concept of tazkiyatu nafs education, there is no discourse on the concept of suluk and tawajuh.

\subsection{The Concept of Suluk}

The word Suluk comes from the terminology of the Qur'an, Fasluki, in Surat an-Nahl verse 69 "Fasluki subula rabbiki zululan" which means "and journey your Rabb-mu has been simplified (for you)". Someone who travels the suluk is called salik. Suluk literally means to follow (path). In suluk Sufism is the effort in pursuing the path to achieve the goal of tariqat. ${ }^{6}$

Suluk is to train the teachings of tariqat to come true. This training is the beginning to be able to follow the Sunnah of the Messenger and hold the syariah'atnya and behave with his morals. Thus the eyes of the eyes are so bright to see the endless sincerity of mortality in Ahadiyat Zat. And also by practicing suluk can validate the qasad / wills with the basis of knowledge and eyes that can guide the faith to present the purpose in front of two eyes by not $^{7}$ seeing besides Him, whether it is maqam and dignity, to be wushul / until after we are lost.

Tariqat Naqsyabandiyah is the only tariqat that possessed the Genealogical transmission of knowledge through the first leader of Islam, Abu Bakr as-Sidiq. Unlike others tariqat, whose Genealogy is based on one of the spiritual leaders, Imam Ali Ibn Abi Thalib.

Just as followers and followers of tariqat are, the truth is the traditions and prophecies of prophethood that have flowed from the time of the prophecy of Adam a. until the prophetic time of Muhammad. The highlight of this tradition and noble character is the prophetic prophet Muhammad. who was born as insan al-kamil. The concept of insan al-kamil is found in the prophet Muhammad. becomes a source of inspiration and motivation for a Sufi in reaching God's light.

Prophetic tradition and character imprinted in the concept of human insan al-kamil is a core force (core force) which is believed by a Sufi to be able to bring them to the true truth, namely "meeting" and "united" with God. ${ }^{8}$

To reach the noble spiritual and aesthetic values of ethics (insan al-kamil) a Sufi performs a number of rituals which are believed to be able to lead them to the most holy

\footnotetext{
${ }^{4}$ Ibid, page 3 .

${ }^{5}$ Ibid....page 5 .

${ }^{6}$ H. A. Mustofa, Akhlak Tasawuf,( Bandung: CV Pustaka Setia, 2010 ), page.285-286.

${ }^{7}$ Abuya Syekh H. Amran Waly Al-Khalidy, Pelajaran Suluk: Dalam Pengamalan Thariqat Naqsyabandiyah Khalidiyah,(Labuhan Haji: MPTT, t.t), page 1.

${ }^{8}$ Ummu Salamah, Sosialisme Tarekat, (Bandung: Humaniora, 2005), page. 1 - 2.

DOI : https://doi.org/10.33258/birci.v2i1.196 
substance. The ritual is sometimes on its own path by the Sufi and can also be carried out by various rituals in congregation.

In the Tariqat Naqshabandiyah to attain the noble ethical and aesthetic values that could be reached by the followers of tariqat by carrying out suluk. Suluk is seclusion under the guidance of murshid to draw closer to Allah. ${ }^{9}$

When walking the path of suluk, a salik is given psycho-spiritual education from the mursyid. Every time, the mursyid always pays attention to the physical and non-physical situations and conditions found in the salik. This condition is a guide for the mursyid in guiding salik. This pattern of education will influence the mindset and remembrance pattern of a salik. Unnoticed by a salik that a murshid has formed a new psychology for salik to always get closer to Allah.

This education with the suluk tradition in the Tariqat Naqsyabandiyah deserves to be presented to the general public as a reflection material closer to Allah, in relation to Islam and sufism, the word suluk means taking the (spiritual) path to Allah. Taking the path of suluk (embroidered) includes a lifelong discipline in carrying out the exoteric rules of Islam (Shari'a) as well as the esoteric rules of the Islamic religion (essence).

Suluk also includes the desire to Know Yourself, Understand the Essence of Life, God's Search, and True Truth (ilahiyyah), through lifelong self-placement by doing syariat lahiriah as well as syariat batiniah in order to attain purity of heart to know yourself and God.

\subsection{The Concept of Tawajuh}

While tawajuh understanding is to face God, tawajuh and suluk are both endeavor to take the path to achieve the goal of tariqat. What distinguishes between tawajuh and tawajuh is the timing of its implementation. Suluk is done in a fast and it takes a long time for days, while tawajuh can be performed in a state of fasting and usually performed once a week. ${ }^{10}$

\subsection{Time of Implentation of suluk and tawajuh}

On every holy month of Ramadan began ten days before the month arrived until the day of Aidil fitri Abuya held a suluk for the people who wanted to chew themselves closer to Allah SWT by practicing the dhikr in addition to performing the prayer in congregation for forty days long nights.Despicated by khalwah or suluk for forty days Abuya also held khalwah or suluk as much as thirty days for the people who did not have time to shed for forty days. Besides there are also titled twenty days and ten days.

In addition to the holy month of Ramadhan, there is also a suluk in the month of Maulid that is 20 days earlier in the early rabiul month. Usually they wait about 2 more nights to celebrate the birth of the Prophet together. In addition, khalwah was also held at the beginning of the month of zulhijjah for 10 days ie from 1 to 10 zulhijjah and closed with Eid al-Adha. ${ }^{11}$

\subsection{Sulukuh and Tawajuh Terms}

\footnotetext{
${ }^{9}$ Fuad Said, Hakekat Tarekat Naqsyabandiyah, (Jakarta: Husna Zikra, 2001), page. 79.

${ }^{10}$ Interview with Tgk.Musliadi, S.Pdi, a teacher and caliph Murshid Suluk at Dayah Darusslam, on November 18, 2016.

${ }^{11}$ Musliadi. Abuya Syeikh Muda Waly Al-Khalidi (1917-1961 M), (Darussalam, 2013), page.162

DOI : https://doi.org/10.33258/birci.v2i1.196 
The terms of Suluk and Tawajuh according to Sheikh Muhammad Walī, then explained by his son Sheikh H.Amran Walī, namely:

a. Mursyid order / Mursyid permission;

b. Seeking for God's pleasure; "O my Lord, You are the one I want and what I ask for You. Give it to me I will love you and know you ";

c. In the case of khalwat, the place of the khalwat is like a grave so that we can disable the will to other than Allah;

d. Minimize the word / word that is just the words that are necessary, because the tongue is the translator of the heart. When we say, then it breaks the heart to God. And it also narrows the cravings of khathar-khatar / memories, either good or bad memories, because it also damages the hearts of God;

e. Decreases eating, as many meals lead to weight and laziness. And it is also lessening the lust of food that is to discuss the science of 'aqli and riyasah / leadership / politics, because it brings great glory and self. The Sufism said: "Your being is a sin for you, can not be compared to other ratios of sin." As for negating the existence and mortality to get the baqa is very demanded;

f. Minimizes sleep, because sleep is body food. It should be reduced gradually, as many sleeps are wasted. And we must be able to perform prayer in congregation, Friday, circumcision, circumcision circumcision, circumcision tahajjud and others;

Such an outline can be made as a condition besides the salik can not eat food from animals / animals, whether it's body, its eggs and others. The conditions of preaching or suluk according to "tanwiru qulub" include:

a. Be sincere, unfaithful and Suma'ah (splendor) is born and born;

b. Asking for prayer permission from sheikh, can not enter Suluk house without his permission during his supervision and education;

c. Uzlah "(alienate), take care of the guard (lack of sleep) and familiarize yourself with hunger, and make a zikir ahead of suluk;

d. Entering the khalwat by stepping on the right foot, asks for protection from God from Satan's temptations, and read bismillah and surah An-Nas three times. Then step on the left foot while reading: $O$ Allah, my protector of the world and the hereafter, make me, what You have made to our leader Muhammad Saw, give me a gift of love. O Allah, cursed me with your beauty and make me your sincere servants. O Allah, remove me with the attraction of your substance, $O$ Most Wise that there is no one who is friendly to Him. Lord, do not let me stay alone, while You are the best heir." Then stood upright in the prayer and said: "Indeed, I have set my face on the one who created the heavens and the earth in a state of righteousness, and I am not among the idolaters. After reading the sentence 11 times, then praying two rak'ahs, after the Al-Fatihah, the Kursi verse and the second rak'ah be read after Al-Fatihah surah Al-Baqarah verse 285. And after greeting reading: "ya Fattahu " as much as 500 times, then then zikir according to the teachings of Sheikh;

e. Always ablution ';

f. Do not be ambitious for obtaining sacred;

g. Do not lean back to the back;

h. Continuing the appearance of the teacher in his eyes;

i. Fasting; 
j. Shut up, except dzikrullah, and something associated with it according to syara 'because it will waste khalwah and eliminate the light of the heart;

k. Stay alert to the four enemy, the devil, the world, the lusts and lusts, by mentioning what is seen to his teacher;

1. Should be far from noise disturbances;

$\mathrm{m}$. Keep the jummah prayer and the prayer of the congregation because the main purpose of khalwat is to follow the Prophet;

n. If forced to go out, have to cover the head to the floor, looking at the ground;

o. Do not sleep, unless you are very sleepy and have to purify (ablution ');

p. Do not sleep because you want to rest, even if you can, do not put the ribs on the floor, and sleep in a sitting position;

q. Keep the middle between hungry and full;

r. Do not open the door to the person who asks for blessings to him, except to Sheikh;

s. All the blessings that he has to acquire should be considered from the Sheikh, while the Sheikh has been from the Prophet;

t. Convolve the vibrations and trails in the heart, both bad and good, because the paths will divide the heart from the unity of remembrance.

\subsection{Procedures for Implementation of Suluk and Tawajuh}

Suluk is alienating from the crowds or to a remote place, to perform zikrullah under the guidance of a shaykh or caliph for 10 days or 20 days and the perfection is 40 days. The rules of nudging are determined by Sheikh, among others; can not eat meat, this happens after crossing the 20-day sulk time. Likewise, it is prohibited to mingle with a husband or wife, eating and drinking is arranged in such a way. Time and all his mind is fully directed to thinking which has been determined by Sheikh or Caliph.

Before the suluk there are several stages; Talqin zikir or bai'at zikir, tawajuh, rabithah, tawassul and zikir. TalqIin or bai'at dhikr begins with a bath of repentance, walks and do rabithah and tawassul when will start zikir. Suluk in the world of tasawuf is also named with khalwat. Khalwat is done to obtain disconnection with the outside world and the focus of the mind so that the atmosphere of concentration to al-Haq (the true substance) and the sincerity of the heart. To achieve that goal, the conditions in certain manners must be implemented in order to achieve the improvement of the intentions, thoughts and consciousness in which each other is related.

Muhammad Mahdi explains that the conditions at every stage to achieve spiritual perfection such as abandoning customs, supervision, awareness, intentions, silence and hunger. It all has a relationship in executing khalwat. The essence of disconnection and eliminating obstacles as well as avoiding things that impede concentration are considered accumulated in it.

Furthermore, at the stage (silence, hunger, abandoning tradition and culture, and professing intentions), where the spiritual master cleansed his mouth with his silence and mood with hunger and the intention of purifying his mind and behavior by abandoning customs and culture and preparing land for khalwat. Because the purpose of these stages is to achieve a state of mutual disconnection with others. So it is clear that khalwat from humans who are associating with them will result in the failure of this goal, will give a positive result. 
Mixing with humans and stumbling blocks can not bring about concentration, spiritual mood and discontinuity.

But be aware that the khalwat for those who walk toward perfection, spiritual happiness, and the essence of man are important. As long as the khalwat intentions have not been realized, then the conventional land is not ready, as will the will, clarity, and sincerity can never be achieved. If so then the spirit can not make the journey in one line and towards the divine orientation. It affects his life with a bustle, anxiety and anxiety.

Social tasks such as association, friendship and moral teaching do not eliminate the meaning of the khalwat. When society is fair and created a dream city, then people are in a state of maturity. Education and teaching, perfection, journey to happiness, the essence of achievement, the quest for makrifat and spiritual in society as it is considered as worship, obedience to God and as a means for consciousness and progress.

Spiritualists carry out the individual and social tasks associated with them, after implementing a special khalwat, then performing public khalwat. He must fulfill his sincere intention and full sincerity. He should not be drifting in the midst of a society that is broken, stupid, unconscious, ineffective, and free. So in the reality of life full of sin there are saints who become examples in society.

\section{Conclusion}

According to Sheikh Muhammad Wali țariqat is part of the teachings of Sufism that is a system / way of cleansing the heart from other than Allah. So our hearts should not be mastered by memory other than Allah. We have to practice 3 things:

a. Rabitah Syarifah, which is to imagine the appearance of the Sheikh between the two luminous eyebrows into our hearts, the deeds, the nature and the substance. Because this Shaykh can remind us of God.

b. Wuquf Qalbi, which unites the will of the sensory thought to God alone, to present God in the heart. Rabithah is before performing wuquf qalbi, and both must be dilazimi, set by simurid at all times and places, even in restroom. And the benefit of doing so is that he can breathe freely in remembrance of God. And so that he can hasten to achieve the purpose / goal, that is the taslim / surrender himself to God, and empty his will to other than Allah, just as much before the person who bathe him. That's how we are before God, God does what He pleases.

c. Dawamuz Zikri / retains remembrance.

According to Shaikh Muhammad Wal̄ in his book "Adab Zikir Ismu Dzat Dalam țariqat Nagsyabandiyah", qalbi is divided into two parts: first, dhikr qalbi with Ismu Dzat ie zikir: Allah, Allah, Allah. Second, zikir qalbi with Nafi Wal Itsbat ie zikir: Laa Ilaaha Illallah. These two zikir are in the heart. 


\section{References}

Al-Khalidy, Abuya Syekh H. Amran Waly, Pelajaran Suluk: Dalam Pengamalan Thariqat Naqsyabandiyah Khalidiyah, Labuhan Haji: MPTT, tt.

Al-Ghazali, Imam, Membersihkan Hati dari Akhlak Tercela, Surabaya:Ampel Mulia, 2003.

Ahmadi, Abu dan Nur Uhbiyati, Ilmu Pendidikan, Cet 2, Jakarta: Rineka Cipta, 2001.

A, Sabri, dkk, Biografi Ulama-Ulama Aceh Abadq XX Jilid I, Cet Pertama, Dinas Pendidikan Provinsi NAD, 2003.

Anwar, Rosihon, Ilmu Tasawuf, Bandung: CV. Pustaka Setia, 2000.

Bruinessen, Marti Van, Tarekat Naqsyabandiyah di Indonesia, cet. I, Bandung: Mizan, 1992.

Bungin, Burhan, Penelitian Kualitatif: Komunikasi, Ekonomi, Kebijakan Publik, dan Ilmu Sosial Lainnya, Cet 3, Jakarta: Kencana, 2008.

Daulay, Haidar Putra dan Nurgaya Pasa, Pendidikan Islam Dalam Mencerdaskan Bangsa, Cet Pertama, Jakarta: Rineka Cipta, 2012.

Daradjat, Zakiah, dkk, Ilmu Pendidikan Islam, Cet.9, Jakarta: Bumi aksara, 2011.

Emzir, Metodologi Penelitian Kualitatif: Analisis Data ,Jakarta: RajaGrafindo Persada, 2011.

Hawwa, Sa'id, Mensucikan Jiwa, Terj. Aunur Rafiq Shaleh Tamhid, Jakarta: Robbani Press, 2000.

H. A. Mustofa, Akhlak Tasawuf, Bandung: CV Pustaka Setia, 2010.

Jazilah, Elis, Metode Tazkiyah An-Nafs sebagai Terapi Bagi Psikomatik, Skripsi: Jurusan Bimbingan dan Penyuluhan Islam, Fakultas Ilmu Dakwah dan Ilmu Komunikasi, UIN Syarif Hidayatullah Jakarta, 2011.

Karzon, Anas Ahmad, Tazkiyatun Nafs: Gelombang Energi Penyucian Jiwa Menurut AlQuran Dan As-Sunnah di Atas Manhaj Salafus Shaalih, Jakarta: Akbar Media, 2010.

Mubarok, Achmad, Jiwa Dalam Al-Qur'an, Jakarta: Pen. Paramadina, 2000.

Musliadi, Abuya Syeikh Muda Waly Al-Khalidi (1917-1961 M), Darussalam, 2013.

Mujiburrahman, dkk, Pendidikan Berbasis Syariat Islam di Aceh, Cet Pertama, Banda Aceh: Dinas Syariat Islam Aceh, 2011.

Makluf, Luis, Al-Munjid fi Al-Lughat wa Al-A'lam, Bairut: Dar Al-Masyriq, 1986.

Mustofa, A, Akhlak Tasawuf, Bandung: Pustaka Setia, 2007.

Mustangin, Khoirul, Metode Tazkiyatun Nafs (Penyucian Jiwa) Melalui Ibadah Sholah dan Implikasinya Terhadap Pendidikan Akhlak (Telaah Pemikiran Imam Al-Ghazali), Skripsi: Fakultas Ilmu Tarbiyah dan Keguruan, Universitas Islam Negeri Sunan Kalijaga Yogyakarta, 2014.

Prihatin, Eka, Konsep Pendidikan, (Bandung: Karsa Mandiri Persada, 2008.

Putra, Riyan Pramono, Konsep Tazkiyatun nafs dan Implikasinya Terhadap Pendidikan Islam, Skripsi: Universitas Pendidikan Indonesia, 2014.

Phoenix, Team Pustaka, Kamus Besar Bahasa Indonesia, Jakarta: Pustaka Phoenix, 2007.

Rice, Cyprian, Berdialog dengan Sufi-sufi Persia, Bandung: Pustaka Setia, 2002.

Shadiqin, Sehat Ihsan, Tasawuf Aceh, Banda Aceh: Bandar Publishing, 2009.

Soyomukti, Nurani, Teori-Teori Pendidikan:Tradisional.(Neo) Liberal, Marxis-Sosialis, postmodern, Cet II, Jogjakarta: Ar-Ruzz Media, 2013.

Sufi, Rusdi dan Agus Budi Wibowo, Pendidikan di Aceh Dari Masa ke Masa, Cetakan Pertama, Banda Aceh: Badan Arsip dan Perpustakaan, 2009

Sugiono, Metode Penelitian Pendidikan Pendekatan Kuantitatif, Kualitatif, dan $R \& D$, Bandung: PT Alfabeta, 2008. 
Sugiono, Metode Penelitian, Bandung: Alfabeta, 2010.

Setyosari, Punaji, Metode Penelitian Pendidikan dan Pengembangannya, Cet.2, Jakarta: Kencana,2012. Saifullah, Muhammad Qutbh dan Sistem pendidikan Non Dikatomik, Yogjakarta: Suluh Pres, 2005.

Salamah, Ummu, Sosialisme Tarekat, Bandung: Humaniora, 2005

Said,Fuad, Hakikat Tarikat Naqsyabandiah, Cet 4, Jakarta: Al-Husna Zikra, 2001.

Shadiqin, Sehat Ihsan, Tasawuf Aceh, Banda Aceh: Bandar Publishing, 2009.

Solihin, M, Ilmu Tasawuf, Bandung: CV Pustaka Setia, 2008.

Umar, Bukhari, Ilmu Pendidikan Islam, Jakarta: Amzah, 2010.

Waly, Muhibbudin, Ayah Kami Maulana Syeikh Haji Muhammad Waly Al-Khalidi, Singapore: JBW PRINTERS \& Binders PTE LDT, 1993 